\section{TOWARDS THE PRECISION MANUFACTURE OF NEW GENERATION OF FUNC- TIONAL POLYMERIC PRODUCTS}

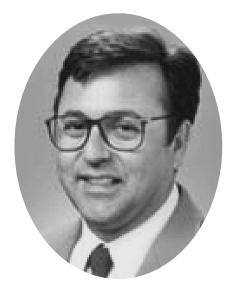

\section{CAKMAK*}

Currently the polymer industry is undergoing a bifurcation in its path to the future. Relatively mature oldest arm is still focused on the traditional materials, processes and applications. This arm of the polymer industry is expected to continue to follow its current path in its incremental evolution as it will continue to serve the vital needs of the population in wide range of useful products while squeezing costs through shifting to cheaper labor markets and less expensive components.

The second arm of the industry is currently in its infancy in transforming itself to produce high value added smart products. This is being facilitated by the availability of new generation of polymers exhibiting unique "functional" properties that include optical, electrical, magnetic performance characteristics. Since these materials have "functional" properties that will serve pivotal role in the success of the future products, they also need to be monitored and controlled. Some of these exciting products include : e-paper, PLED's, photonic crystal structures promising to provide building blocks of future optical computers, inexpensive biochips, smart nanofiber based band aids that deliver wound healing NO gas directly to the wound. Obviously the interface between the currently undergoing nano revolution and polymer field promises to be very fertile for exciting idea generation and product developments.

The common theme in all of these emerging applications is they all need to be controlled into much higher tolerances that have traditionally been demanded of the "commodity" applications. In addition, precision dimensional control of the products down to molecular scale will be necessary but not sufficient to guarantee their optimum performance as we also must concurrently sense, predict and control the functional properties that are almost always process history dependent. We not only need to do these well but we also need to do it fast to be price competitive with other materials.

Following are some of the challenges that we will be dealing with in coming decade :

For the materials of the future to be precision manufactured, we must understand and develop quantitative relationships to mathematically describe the complex interplay between the materials and processes used to convert them into useful products. Specifically, we need relationships that link the processing variables to flow in- duced structuring : crystallization, phase structural hierarchy, specific property (optical, phase behavior, electrical, etc) and their anisotropy. Current research on the on-line measurement techniques that couple true process variables with structural parameters are gradually helping us decipher the complex phenomena that typically occurs when we subject the materials to sometimes severe chemical, thermal, deformation histories.

The future is brighter than ever for the polymers as these high value added markets based on functional polymers will develop in accelerating pace in the coming decades and it promises to revolutionize the polymer industry. On this journey, everyone in academia, industry and governments will have vital roles to play.

\footnotetext{
* Polymer Engineering Institute

University of Akron

Akron, OH 44325-0301, USA
}

\section{日本の成形加工}

\section{TUBAGUS. N. H.*}

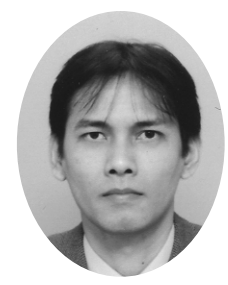

技術力や品質については高い評価を受けてきた日本は最 先端の研究開発・教育を行い,アジアをリードしている. 海外では日本の技術を取り入れて製品開発を行おうとして いるという話を最近よく耳にするが， Made in Japan とい うブランドに対する製品の信頼性がいうまでもなく高い評 価を受けている.

近年，時代の変化は激しくなっており，成形加工技術に おいて，次の何十年先を見据えたとき，今までの技術力を ベースに，より便利なもの，そして必要なものを作ること を考える必要がある，そのために，まずリサイクル性を考 えた成形加工である．部品を少なくする技術や土に還るプ ラスチックに代表されるような, リサイクル方法や分離・ 分解技術の開発を進め, 他のさまざまな材料にも適応でき たら数十年数百年先の地球を守ることに繋がると思う. 次 に新しい機能を付加した材料開発である，たとえば，医療 の面からは，数十年間体内に入れたままでも良くなじみ， 劣化や患者への負担が少なく，かつ身体の一部と同じよう な機能を併せ持つ材料の開発も今後興味深いテーマになる と思う。

最後に今よりも適用性が広い成形加工の技術である。例 えば，ファイバースコープへの適用があげられる，毛細血 管よりもずっと細いファイバースコープが開発されば，患 者への負担が少なく，医療の幅も広がると思う.

夢物語を書き連ねてみたが, 日本の成形加工は最先端の 技術開発・研究・教育を行うことで, 海外特にアジアの次 世代の若者達にも希望・機会・夢を与える. 
* Nouval Haedar Tubagus

(株計算力学研究センター

東京都品川区戸越 1-7-1 NI ビル（テ142-0041）

\section{手造り成形の夢}

成澤郁夫*

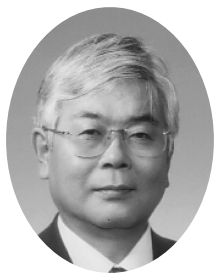

プラスチックがこれだけ普及する背景には，材料そのも のの優れた特性もあるが，なんといっても大量生産に向く 加工性の良さが決め手になっている．金属部品で作れば何 工程も経なければならないのが，たった 1 回の成形で同じ ものができるということは，大量生産・大量消費型で使い 捨てを前提とする成長経済にぴったり適合する。したがっ て，プラスチックの成形技術も高速，高能率，高生産性な どをどのようにして実現するかということを中心に研究や 開発が行われてきたということにつきる。このような結果, 結局は激しいコスト競争に巻き込まれ，気がつけば成形の 拠点や技術さえも人件費の安い東南アジアや中国に移って しまっていたというのが日本の現実のようである。いや， まだ精度のよい金型は中国ではまだ作れないなどという意 見もあるが，いずれは追いつかれることは，韓国・台湾の 追い上げの例を見ればよく分かる．もともと，加工研究は 製造現場がなければ成立しないものであり，日本ではその 現場が減りつつあることを考えても，大量生産を支える技 術開発はすでに限界にきているのではないだろうか.

このような状況を打開するために，技術の囲い达みや先 端技術などの開発が必要であると主張されているが, 一方 では資源枯渴や環境問題が深刻になり, 大量生産・大量消 費という経済のシステムの見直しを迫られている．確かに 均質な規格品を大量に作るという生産技術はわれわれの日 常生活を豊かにしてくれたが，同時に差別化された本物志 向の傾向も高まっている。このような状況を判断すると， 生産性だけ求めてきた従来の成形加工技術を根本から考え 直す時機にさしかかっているのではないかと思う。歴史や 自然に学ぶというのは，研究や開発の基本的な手法である が，かつては非効率とか工業的ではないと切り捨てられた 材料や技術にもう一度焦点を当ててみるのもそのひとつで ある．代替品とかまがい物といわれることもなく，プラス チックでなければできないようなもので,

しかも数少なくてもデザインオーダーに応じられるよう な，いわば手造りに近い加工方法を探して見たいというの が今年の夢である.

\footnotetext{
* Narisawa, Ikuo

NIT リサーチ NIT Research

那須塩原市北弥六 414-22（３29-3132）
}

\section{最適成形条件の自動補正}

\author{
萩原明彦*
}

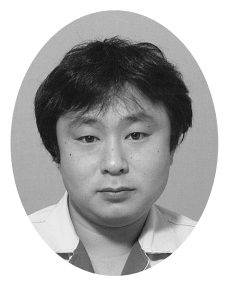

近年，複数台の成形機とコンピュー夕を接続した群管理 システムの導入により，成形条件の履歴㧍よび品質モニ夕 リングデータをリアルタイムで監視・制御することが可能 となり, 成形工場のリードタイム短縮と品質の向上が図ら れている.

また, 型内の樹脂挙動を解析する CAE は, 製品のソリ, ヒケ，ショート，ウエルドといった成形不良の予測能力が 向上してきており，品質改善ツールとして充害化が図られ ている.さらに，CAEがインストールされたコンピュー 夕を成形機に接続して，成形と解析を並行して行うことに より，最適な成形条件を見つけ出すといったシステムが構 築されてきている.

$\mathrm{CAE}$ と成形機を接続し，最適な成形条件が決定されれ ば，その成形条件を正確に再現させればよいことになる。 しかし, 成形工場では, 成形機・金型・樹脂の状態が常に 同一であるとは限らない。よって，これらの状態変化を取 り达み，結果を予測して，成形条件を自動補正する機能を 追加したい。

射出成形は，可塑化・流動・固化の 3 つの工程がある. $\mathrm{CAE}$ は, 型内の樹脂挙動（流動・固化）を解析すること が主であるが，成形条件を自動補正するためには，型内に 流入される前の樹脂挙動（可塑化）をつかむことも要求さ れてくる.

精密小型部品成形においては，耐熱性に優れた樹脂が多 く使用されている。これらの樹脂は, 溶融温度が高く, 過 熱により分解劣化を起こしやすく, 成形可能な温度範囲が 狭いため, 可塑化工程において最適な溶融状態を探し，均 一な樹脂温度に安定させることが重要である。

樹脂の溶融状態は，スクリュデザイン，バレルヒータの 温度制御，ホッパ口形状だけでなく，スクリュ，バレルの 摩耗状態の影響もある。また，ペレットサイズ，粉砕材の 有無，ペレットの乾燥状態といった樹脂を溶かす前の状態 にも左右される. よって，可塑化工程における自動補正は， ホッパ口に投入される前からスクリュ先端までの樹脂挙動 を把握する必要がある。また，スクリュデザインと樹脂の 相性がマッチしない，あるいはスクリュ，バレルの摩耗進 行等をユーザに知らせる様な機能も欲しい.

このように射出成形機における各工程の樹脂挙動を把握 し，最適な成形条件を自動補正できる機能が組み込まれれ ば，成形技術者の大きな手助けになると思われる。

\footnotetext{
* Hagiwara, Akihiko

東芝機械侏) 射出成形機技術部

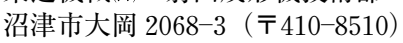

